\title{
Under pressure: pulmonary hypertension associated with left heart disease
}

\author{
Harrison W. Farber ${ }^{1}$ and Simon Gibbs ${ }^{2}$ \\ Affiliations: ${ }^{1}$ Pulmonary Center, Boston University School of Medicine, Boston, MA, USA. ${ }^{2}$ National Heart and \\ Lung Institute, Imperial College London and Hammersmith Hospital, London, UK.
}

Correspondence: Harrison W. Farber, Pulmonary Center, Boston University School of Medicine, 72 East Concord Street, R-304, Boston, MA 02118, USA. E-mail: hfarberabu.edu

ABSTRACT Pulmonary hypertension (PH) associated with left heart disease (PH-LHD) is the most common type of $\mathrm{PH}$, but its natural history is not well understood. PH-LHD is diagnosed by right heart catheterisation with a mean pulmonary arterial pressure $\geqslant 25 \mathrm{mmHg}$ and a pulmonary capillary wedge pressure $>15 \mathrm{mmHg}$. The primary causes of PH-LHD are left ventricular dysfunction of systolic and diastolic origin, and valvular disease. Prognosis is poor and survival rates are low. Limited progress has been made towards specific therapies for PH-LHD, and management focuses on addressing the underlying cause of the disease with supportive therapies, surgery and pharmacological treatments. Clinical trials of therapies for pulmonary arterial hypertension in patients with PH-LHD have thus far been limited and have provided disappointing or conflicting results. Robust, long-term clinical studies in appropriate target populations have the potential to improve the outlook for patients with PH-LHD. Herein, we discuss the knowledge gaps in our understanding of PH-LHD, and describe the current unmet needs and challenges that are faced by clinicians when identifying and managing patients with this disease.

$\boldsymbol{0}$

@ERSpublications

Pulmonary hypertension due to left heart disease is associated with multiple unmet medical needs http://ow.ly/TFET8

\section{Case study part 1: initial assessment}

A 63-year-old male with hypertension, diabetes mellitus, dyslipidaemia, coronary artery disease and obstructive sleep apnoea presented to the clinic with worsening dyspnoea upon exertion (World Health Organization (WHO) functional class IIIb). Echocardiography revealed a normal-sized left ventricle, left ventricular ejection fraction (LVEF) of $35-40 \%$, delayed left ventricular diastolic relaxation, normal left atrium, right ventricular dilation with moderately depressed systolic function, mild right atrial enlargement, flattened interventricular septum, dilated inferior vena cava, and a pulmonary artery systolic pressure of $85 \mathrm{mmHg}$. Computed tomography pulmonary angiography revealed no pulmonary embolus or parenchymal lung disease. The patient failed to reach the target heart rate in a treadmill exercise test, but there was no evidence of myocardial ischaemia. Pulmonary function testing and right heart catheterisation (RHC) were performed (table 1).

Question 1: Based on these data, what would be your initial assessment of this patient?

This real-life patient case study highlights some of the many factors that can make diagnosing pulmonary hypertension associated with left heart disease (PH-LHD) challenging. Based on the information presented, would you diagnose this patient with PH-LHD?

Received: Aug 212015 | Accepted after revision: Oct 142015

Conflict of interest: Disclosures can be found alongside the online version of this article at err.ersjournals.com

Provenance: Publication of this peer-reviewed article was sponsored by Actelion Pharmaceuticals Ltd, Allschwil, Switzerland (principal sponsor, European Respiratory Review issue 138).

Copyright OERS 2015. ERR articles are open access and distributed under the terms of the Creative Commons Attribution Non-Commercial Licence 4.0. 
TABLE 1 Case study: results from pulmonary function testing and right heart catheterisation

$\begin{array}{ll}\text { Pulmonary function testing } & \\ \text { Forced vital capacity } & 2.96 \mathrm{~L}(74 \% \text { pred) } \\ \text { FEV1 } & 2.31 \mathrm{~L}(81 \% \mathrm{pred}) \\ \text { Total lung capacity } & 5.99 \mathrm{~L}(98 \% \mathrm{pred}) \\ \quad \text { DLCo } & 20.23 \mathrm{~mL} \cdot \mathrm{min}^{-1}(79 \% \mathrm{pred}) \\ \text { Right heart catheterisation } & \\ \text { Mean right atrial pressure } & 7 \mathrm{mmHg} \\ \text { Right ventricular pressure } & 70 / 3 \mathrm{mmHg} \\ \text { Pulmonary arterial pressure } & 72 / 34 \mathrm{mmHg} \\ \text { Pulmonary artery wedge pressure } & 13 \mathrm{mmHg} \\ \text { Cardiac output/cardiac index } & 2.3 / 1.2 \mathrm{~L} \cdot \mathrm{min} \cdot \mathrm{m}^{-2} \\ \text { Pulmonary vascular resistance } & 1251 \mathrm{dyn} \cdot \mathrm{s} \cdot \mathrm{cm}^{-5}(15.6 \text { Wood units) } \\ \text { Systemic vascular resistance } & 3614 \mathrm{dyn} \cdot \mathrm{s} \cdot \mathrm{cm}^{-5}(45.2 \text { Wood units) }\end{array}$

FEV1: forced expiratory volume in $1 \mathrm{~s}$; DLCo: diffusing capacity of the lung for carbon monoxide.

\#: measured by thermodilution.

In this review, we will discuss the challenges that are associated with diagnosing and managing PH-LHD, before revisiting the case study at the end of this article. The topics that will be presented here might change your evaluation of this patient's diagnosis.

\section{Introduction}

PH-LHD is a common form of pulmonary hypertension $(\mathrm{PH})$ that is associated with a poor prognosis and high rate of morbidity and mortality $[1,2]$. However, there is still a lack of understanding about its pathophysiology, epidemiology and treatment [1-14]; as such, there are numerous unmet needs for this condition (table 2). Multiple disorders are responsible for PH-LHD, including: 1) left ventricular systolic dysfunction (heart failure with reduced ejection fraction (HFrEF)); 2) left ventricular diastolic dysfunction (heart failure with preserved ejection fraction (HFpEF)); 3) left-sided valvular disease; and 4) congenital/ acquired left heart inflow/outflow tract obstruction and congenital cardiomyopathies $[2,5]$. In many cases of PH-LHD, there is a degree of overlap in these aetiologies [5].

PH-LHD is characterised by backwards transmission of filling pressures due to impaired left ventricular diastolic function. A loss of left atrial compliance, exercise-induced mitral regurgitation and diastolic dysfunction, combined with increased pulsatile load caused by the increased pulmonary artery wedge pressure (PAWP), can lead to and/or exacerbate the $\mathrm{PH}$ [4]. Increases in mean pulmonary arterial pressure (PAP) in certain individuals may trigger development of PH. In some patients, additional factors, such as endothelial dysfunction (resulting in decreased nitric oxide availability and increased expression of endothelin) [15], an altered response to brain natriuretic peptide (BNP) (impacting vascular tone) [16], and vasoconstriction and/or vascular remodelling [3], can lead to further increases in vascular resistance and, hence, raised PAP [4]. As such, extensive vascular remodelling can occur in PH-LHD, resulting in decreased vascular compliance; right ventricle overload and right ventricular failure can then ensue, eventually leading to death [4]. It is important to remember that the most common cause of right ventricular dysfunction is still chronic heart failure [17]

There is no consensus regarding the true prevalence of PH-LHD in heart failure; it is estimated that up to $80 \%$ of patients with heart failure develop $\mathrm{PH}$, depending on the methodology used to provide the

TABLE 2 Unmet needs for pulmonary hypertension associated with left heart disease (PH-LHD)

A better understanding of the natural history

Information about the disease prevalence

Better definitions of clinical trial study populations and study end-points

Availability of specific therapies

An understanding of the potential interactions of PH-LHD comorbidities and concomitant medications

Improved patient prognosis 
estimates [18-23]. $\mathrm{PH}$ is common in patients with HFpEF and can be severe; $50 \%$ of patients with heart failure will have HFpEF [18]. Depending on the method of detection, $\mathrm{PH}$ has been shown to occur in $\geqslant 60 \%$ of patients with systolic dysfunction $[6,24]$. In patients undergoing heart transplantation, $\mathrm{PH}$ has been reported as the cause of perioperative death in $44 \%$ of cases. Furthermore, the presence of $\mathrm{PH}$ could be considered a contraindication for carrying out transplantation [25].

In this review, we discuss the knowledge gaps in our understanding of PH-LHD and challenges faced by clinicians in the diagnosis and management of patients with PH-LHD. This review also provides an overview of how PH-LHD is currently managed in patients, and reflects on a number of potential strategies that might improve patient outcomes.

\section{Classification and diagnosis of PH-LHD}

Differential diagnosis of PH-LHD from other forms of $\mathrm{PH}$ can be highly challenging due to misunderstandings about the determinants of the disease, heterogeneity in the definitions and terminology, and variations in the different haemodynamic presentations. PH-LHD belongs to group 2 of the World Symposium on Pulmonary Hypertension PH clinical classification [26]. This group is defined as post-capillary $\mathrm{PH}$, characterised by a mean PAP of $\geqslant 25 \mathrm{mmHg}$ and PAWP of $>15 \mathrm{mmHg}$ (fig. 1) [26, 27]. In contrast, the haemodynamic definition of pre-capillary $\mathrm{PH}$ differs from post-capillary $\mathrm{PH}$ in that PAWP is $\leqslant 15 \mathrm{mmHg}$ [27]. Pulmonary arterial hypertension (PAH) (group 1), $\mathrm{PH}$ due to pulmonary disease (group 3), chronic thromboembolic $\mathrm{PH}$ (group 4), and $\mathrm{PH}$ with unclear and/or multifactorial mechanisms (group 5) are all types of pre-capillary PH [27]. Thus, group $2 \mathrm{PH}$ is the only current classification that is characterised purely by post-capillary $\mathrm{PH}$ (some of the entities in group 5 can involve both post- and pre-capillary mechanisms).

\section{Challenges in diagnosis}

A major challenge associated with diagnosing PH-LHD is the variation in terminology. $\mathrm{PH}$ is a known result of left-sided heart failure, regardless of the cause [18]. When differentiating HFpEF from HFrEF it is important to consider that although patients in both subgroups will present with signs and symptoms of heart failure, HFrEF is associated with a marked reduction in LVEF, whereas HFpEF is associated with a normal LVEF [18]. Management strategies and outcomes for patients with HFpEF and HFrEF may differ; however, differentiating between these two states can be challenging [28].

Differentiating between pre- and post-capillary $\mathrm{PH}$, especially in patients with HFpEF, can also be diagnostically challenging. Misdiagnosis of PH-LHD as PAH could result in patients receiving inappropriate, or even detrimental, therapies [4]. In addition, a previously elevated but now normalised PAWP (with persistence of pulmonary vascular disease) can be seen in patients who have received diuretics and/or undergone the overnight fast associated with catheterisation. This is often the case in patients with HFpEF [4], leading to confusion between group 2 and group $1 \mathrm{PH}$ patients at the time of catheterisation.

Variations in how to describe the different haemodynamic components is another potential cause of confusion in PH-LHD. Previous definitions categorised patients as having "passive" or "reactive" (also

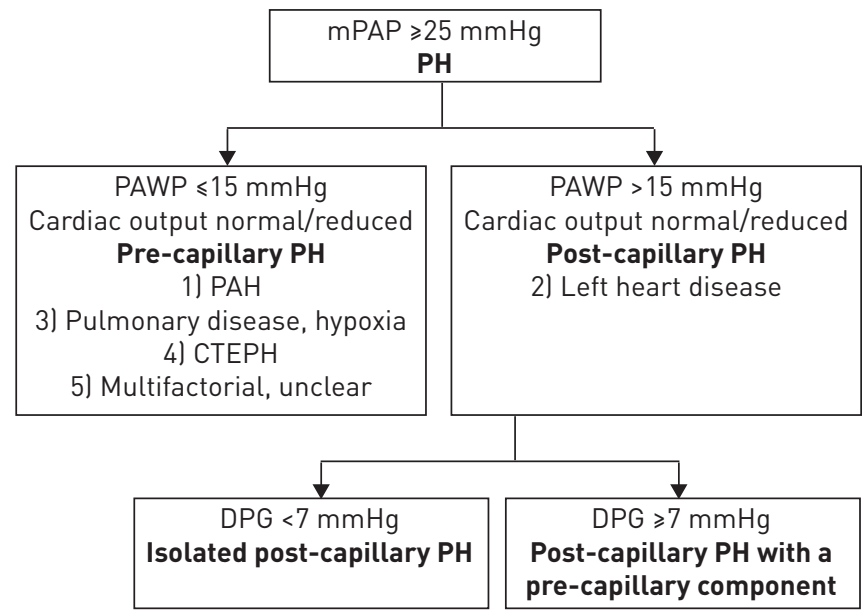

FIGURE 1 Definition of pulmonary hypertension (PH) associated with left heart disease. mPAP: mean pulmonary arterial pressure; PAWP: pulmonary artery wedge pressure; PAH: pulmonary arterial hypertension; CTEPH: chronic thromboembolic pulmonary hypertension; DPG: diastolic pressure gradient. Information from $[4,26,27]$. 
termed "out of proportion") disease [4, 29]. An updated classification for post-capillary haemodynamics has recently been proposed [4]. This method takes into account the diastolic pressure gradient (DPG) (defined as the difference between diastolic PAP and mean PAWP), and defines patients with a low DPG $(<7 \mathrm{mmHg}$ ) and PAWP $>15 \mathrm{mmHg}$ as having isolated post-capillary $\mathrm{PH}$, but patients with DPG $\geqslant 7 \mathrm{mmHg}$ and PAWP $>15 \mathrm{mmHg}$ as having post-capillary $\mathrm{PH}$ with a pre-capillary component (fig. 1) [4].

\section{What is the advantage of this new definition?}

Defining PH-LHD based on DPG has several advantages in classifying patients, including the fact that DPG is low in healthy individuals and is relatively simple to calculate. Relying on measurement of the DPG to distinguish between post-capillary PH with a pre-capillary component enables assessment of a patient's status while avoiding assumptions about the haemodynamic components of vasoconstriction and remodelling [23]. An association between elevated DPG and vascular remodelling, which is associated with significant pulmonary vascular disease and increased risk of mortality, has been demonstrated by a single study [30]. However, the prognostic benefit of this measurement might be limited, as factors other than vascular remodelling can lead to increases in DPG [31]. In a large study of patients with heart failure undergoing heart transplantation, DPG did not predict post-transplant survival [31]. In the 2015 guidelines for the diagnosis and treatment of PH [27], the joint task force of the European Society of Cardiology (ESC) and the European Respiratory Society (ERS) recommends that a combination of pulmonary vascular resistance (PVR) and DPG should be used to define the different types of PH-LHD: isolated post-capillary pulmonary hypertension (DPG $<7 \mathrm{mmHg}$ and/or PVR $\leqslant 3$ Wood units) and combined post-capillary and pre-capillary pulmonary hypertension (DPG $\geqslant 7 \mathrm{mmHg}$ and/or PVR $>3$ Wood units). Furthermore, these guidelines state that patients with PH-LHD who have a high DPG and/or PVR should be referred to an expert PH centre for a complete diagnostic work-up and decisions about treatment [27].

\section{Diagnostic methods}

Several invasive and noninvasive methods can be used for diagnosis of suspected PH-LHD [2]. An understanding of patient comorbidities and disease risk factors can greatly assist with the differential diagnosis from other conditions and types of $\mathrm{PH}$. Medical history review can help determine the clinical course and evaluate risk factors such as orthopnoea and paroxysmal nocturnal dyspnoea [2]. Physical examination can detect pulmonary oedema and pleural effusions [2], as well as signs of cardiac enlargement, left-sided S3 or S4 and murmurs consistent with valvular disease [6]. If PH is suspected, echocardiography can evaluate the patient's ventricular and valve function [6]. Laboratory tests can rule out anaemia and renal, thyroid or hepatic dysfunction [6]. The level of BNP and N-terminal pro-brain natriuretic peptide (NT-proBNP) can also be measured [6]; in patients with acute HFpEF a high level of NT-proBNP is a risk factor for poor short-term prognosis [32].

Cardiac catheterisation can be used to distinguish pre- and post-capillary PH [23, 33, 34]. As well as assessing pulmonary haemodynamics, catheterisation can be used to identify coronary artery disease and valvular disease and to measure left-sided filling pressure, if necessary by direct measurement of left ventricular pressure $[4,6]$. One of the pitfalls of relying on RHC for differentiating PAH from PH-LHD is that most patients will be in a fasted and diuresed state, which can lead to underestimation of left heart filling pressure [22]. Administration of $\sim 500 \mathrm{~mL}$ saline to patients undergoing RHC has been shown to increase PAWP, which could help differentiate patients with PAH from those with occult left ventricular dysfunction [35]. However, as yet, this technique has not been validated, although it has recently been recommended [36].

Vasoreactivity testing can be used to assess PH reversibility in cardiac transplant candidates [6]. This can be carried out at the same time as RHC, and involves the administration of parenteral nitroprusside, nitroglycerin or inhaled nitric oxide, with close titration, to achieve a positive vasodilator response (reduction in PVR to $<2.5$ Wood units) [37]. However, vasoreactivity testing in nontransplant candidates with PH-LHD has not been investigated and is currently not recommended, as there is currently no internationally accepted protocol for this procedure $[4,33]$.

\section{Prognosis}

PH-LHD is associated with a poor prognosis, and high risk of morbidity and mortality $[3,29,38-40]$. The 12 -month mortality rates for PH-LHD have been estimated to be as high as $32 \%$, with predictors of mortality including older age, male sex, right ventricular dysfunction, renal disease and lower functional class [41]. Among patients with advanced heart failure, reduced right ventricular ejection fraction (RVEF) (using a value of $<35 \%$ as a surrogate for right ventricular systolic dysfunction) is associated with a high risk of death or the need for urgent transplantation, whereas patients with preserved RVEF have a prognosis that is very similar to patients with normal PAP [39]. Furthermore, in a large cohort of patients 
with chronic HFrEF (LVEF $\leqslant 40 \%$ ), those with pre-capillary PH, as determined by PVR $\geqslant 3$ Wood units, mean PAP $\geqslant 25 \mathrm{mmHg}$ and PAWP $\geqslant 15 \mathrm{mmHg}$, were found to have a greater risk of death than patients with PH-LHD (PVR $<3$ Wood units, mean PAP $\geqslant 25 \mathrm{mmHg}$ and PAWP $\geqslant 15 \mathrm{mmHg}$ ) (hazard ratio 1.55 , 95\% CI 1.11-2.20; $\mathrm{p}<0.001$ ), suggesting that PH-LHD in HFrEF carries a greater risk of death than when other types of $\mathrm{PH}$ are present [42]. Among patients with PH-LHD who have acute decompensated heart failure, 6-month survival rates are lower in patients with post-capillary $\mathrm{PH}$ with a pre-capillary component than those with isolated post-capillary $\mathrm{PH}$ (48.3\% versus $21.8 \%$ mortality, respectively) [38].

Prognosis in patients with heart failure can be determined by measuring RVEF [43-46]. In moderate congestive heart failure, RVEF has been shown to be an independent predictor of survival, with 1-year survival rates for $\mathrm{RVEF}<25 \%, \geqslant 25 \%$ to $<35 \%$ and $\geqslant 35 \%$ of $80 \%, 90 \%$ and $95 \%$, respectively [43]. Moreover, increased PAP (mean PAP $>20 \mathrm{mmHg}$ ) coupled with low RVEF $(<35 \%)$ is associated with lower patient survival than normal PAP plus preserved/low RVEF or high PAP/preserved RVEF [39]. In patients with PH-LHD due to HFpEF, right ventricular systolic dysfunction is associated with higher mortality than patients with pulmonary artery systolic pressure $>47 \mathrm{mmHg}$, even after adjustment for age and pulmonary artery systolic pressure [29].

\section{Management of PH-LHD}

Although a treatment algorithm has been developed for group $1 \mathrm{PH}(\mathrm{PAH})$ in the ESC/ERS guidelines, it does not apply to patients with PH-LHD [27]. Prior to the assessment of patients for PH-LHD, the ESC/ ERS guidelines recommend that treatment of underlying conditions should be optimised and any other causes of PH should be ruled out [27]. General supportive therapies for PAH include supplemental oxygen, diuretics, oral anticoagulants and digoxin, and specific drug therapy includes calcium channel blockers, prostanoids, endothelin receptor agonists, soluble guanylyl cyclase stimulators and phosphodiesterase type-5 inhibitors [27]. There is currently no similar approved specific therapy for PH-LHD; furthermore, clinical trial data for these patients are lacking [2-4]. Managing the underlying cause of $\mathrm{PH}$ is an important first step in treating PH-LHD [4]. For example, in the case of left heart disease due to valve disease, surgical repair or replacement of mitral or aortic valves can improve patient outcomes [2, 3, 47]. Reducing left heart filling pressures can also be achieved using established treatments for heart failure [2]. Diuretics are the mainstay of medical treatment for fluid control and relief of congestion, whereas angiotensin-converting enzyme inhibitors and $\beta$-blockers are indicated to improve outcomes in heart failure associated with HFrEF [23].

Several clinical trials have investigated the use of PAH therapies (e.g. prostanoids, endothelin receptor antagonists and phosphodiesterase type 5 inhibitors) in patients with suspected PH-LHD [48-60]; however, there is no clinical evidence to support the use of PAH therapies in the clinical management of patients with PH-LHD [27]. The results of studies that have investigated PAH-specific therapies in PH-LHD (many of which are summarised in table 3 ) have generally been negative and some could even be regarded as harmful. Furthermore, some of the trials that have been carried out have been prospective, randomised, placebo-controlled studies, while others have been retrospective, open-label studies. Studies of sildenafil in PH-LHD have been inconsistent; while some have seen improvements in exercise capacity, haemodynamics and quality of life in patients with systolic and diastolic heart failure [53, 55], others have found no benefit $[59,62]$.

There are several limitations to clinical trials for pharmacological agents in PH-LHD. Patients are seldom stratified by the underlying cause of $\mathrm{PH}$, and haemodynamic evaluation is not carried out systematically [23]. It has been recommended that patients with post-capillary $\mathrm{PH}$ with a pre-capillary component should represent the target population for clinical trials [4]; however, there are very few current studies in this patient population. In addition, it has been recommended that trial end-points should assess safety first, and efficacy can then be based on measurable clinical outcomes [4]. One of the few trials to address the limitations of previous studies is MELODY-1 [57], an ongoing trial that is evaluating the safety and tolerability of macitentan, an endothelin receptor antagonist, in patients with post-capillary PH with a pre-capillary component. The primary (safety) outcome will be the proportion of patients experiencing significant fluid retention or a worsening of WHO functional class from baseline. The secondary (efficacy) outcomes will be the change from baseline in cardiopulmonary haemodynamic parameters and echocardiographic parameters of systolic and diastolic function after 12 weeks of treatment [57].

In conjunction with specific pharmacological strategies for managing PH-LHD, treating patients' underlying comorbidities is beneficial, e.g. the aggressive control of cardiovascular risk factors [23]. Obesity frequently coexists with $\mathrm{PH}$, and in severe obesity an excess volume load is placed on the left ventricle, which can eventually lead to heart failure [63]. Haemodynamic improvement has been observed with bariatric surgery for PH [64], and this could be explored further as a potential therapy for PH-LHD in patients who have concomitant obesity. 
TABLE 3 Completed and ongoing trials of pulmonary arterial hypertension (PAH)-specific therapies in patients with suspected pulmonary hypertension associated with left heart disease (PH-LHD)

\begin{tabular}{|c|c|c|c|c|c|c|}
\hline Drug, year [ref.] & $\begin{array}{l}\text { Study acronym/ } \\
\text { identifier" }\end{array}$ & Subjects $n$ & Patient characteristics & Design & Primary end-point & Key results \\
\hline $\begin{array}{l}\text { Epoprostenol } \\
1996[51]\end{array}$ & FIRST & 471 & $\begin{array}{l}\text { Severe heart failure, } \\
\text { WHO FC IIIb-IV }\end{array}$ & $\begin{array}{l}1: 1 \text { randomisation } \\
\text { Event-driven } \\
\text { Mean dose } 4 \mathrm{ng} \cdot \mathrm{kg}^{-1} \cdot \mathrm{min}^{-1}\end{array}$ & Survival & $\begin{array}{l}\text { Early termination (trend to decreased survival } \\
\text { in treated group) }\end{array}$ \\
\hline $\begin{array}{l}\text { Bosentan } 2002 \\
\quad[50]\end{array}$ & ENABLE & 1613 & $\begin{array}{l}\text { Severe heart failure, } \\
\text { WHO FC IIIb-IV }\end{array}$ & $\begin{array}{l}1: 1 \text { randomisation } \\
18-\text { month duration } \\
125 \text { mg twice daily }\end{array}$ & Mortality and hospital stays & $\begin{array}{l}\text { No effect } \\
\text { Early risk of worsening heart failure } \\
\text { necessitating hospitalisation due to fluid } \\
\text { retention with treatment }\end{array}$ \\
\hline $\begin{array}{l}\text { Bosentan } 2005 \\
\text { [49] }\end{array}$ & REACH-1 & 370 & $\begin{array}{l}\text { Severe heart failure, } \\
\text { WHO FC IIIb-IV }\end{array}$ & $\begin{array}{l}\text { 1:1:1 randomisation } \\
26 \text {-week duration } \\
500 \mathrm{mg} \text { twice daily via rapid or slow } \\
\text { infusion }\end{array}$ & Change in clinical status & $\begin{array}{l}\text { No effect } \\
\text { Early termination (safety concerns) }\end{array}$ \\
\hline $\begin{array}{l}\text { Darusentan } 2002 \\
\quad[56]\end{array}$ & HEAT & 179 & $\begin{array}{l}\text { Chronic heart failure, } \\
\text { WHO FC III }\end{array}$ & $\begin{array}{l}\text { 1:1:1:1 randomisation } \\
3 \text {-week duration } \\
\text { Doses of } 30,100 \text { and } 300 \mathrm{mg} \text { daily }\end{array}$ & $\begin{array}{l}\text { Haemodynamics (change in } \\
\text { PAWP/cardiac index) }\end{array}$ & $\begin{array}{l}\text { Increased cardiac index } \\
\text { No change in PAWP }\end{array}$ \\
\hline $\begin{array}{l}\text { Darusentan } 2004 \\
\quad[52]\end{array}$ & EARTH & 642 & $\begin{array}{l}\text { Chronic heart failure, } \\
\text { WHO FC II-IV }\end{array}$ & $\begin{array}{l}\text { 1:1:1:1:1 randomisation } \\
\text { 6-month duration } \\
\text { Doses of } 10,25,50,100 \text { and } 300 \mathrm{mg} \\
\quad \text { daily }\end{array}$ & $\begin{array}{l}\text { LVESV changes by MRI and } \\
\text { clinical events }\end{array}$ & No effect \\
\hline $\begin{array}{l}\text { Sildenafil } 2007 \\
\text { [53] }\end{array}$ & NCT00309816 & 13 & $\begin{array}{l}\text { Heart failure, WHO FC } \\
\text { III }\end{array}$ & $\begin{array}{l}\text { Nonrandomised, open-label } \\
50 \mathrm{mg} \text { single dose }\end{array}$ & $\begin{array}{l}\text { Exercise capacity and } \\
\text { haemodynamics after } 60 \mathrm{~min}\end{array}$ & $\begin{array}{l}\text { Significant reduction in resting PAP, SVR and } \\
\text { PVR, and increased resting and exercise } \\
\text { cardiac index }(p<0.05)\end{array}$ \\
\hline $\begin{array}{l}\text { Sildenafil } 2007 \\
\text { [55] }\end{array}$ & NCT00309790 & 34 & $\begin{array}{l}\text { Heart failure, WHO FC } \\
\text { II-IV }\end{array}$ & $\begin{array}{l}1: 1 \text { randomisation } \\
12-\text { week duration } \\
25-75 \mathrm{mg} \text { three times daily }\end{array}$ & $\begin{array}{l}\text { Haemodynamics (change in } \\
\text { peak } V^{\prime} \mathrm{O}_{2} \text { ) }\end{array}$ & Significantly greater increase in $V^{\prime} o_{2}(p=0.02)$ \\
\hline $\begin{array}{l}\text { Sildenafil } 2007 \\
\text { [54] }\end{array}$ & NCT00407446 & 46 & $\begin{array}{l}\text { Chronic heart failure, } \\
\text { WHO FC II-III }\end{array}$ & $\begin{array}{l}1: 1 \text { randomisation } \\
6 \text {-month duration } \\
50 \mathrm{mg} \text { twice daily }\end{array}$ & $\begin{array}{l}\text { Exercise performance, ventilation } \\
\text { efficiency, symptoms }\end{array}$ & $\begin{array}{l}\text { Significant increases at } 3 \text { and } 6 \text { months } \\
(p<0.01)\end{array}$ \\
\hline $\begin{array}{l}\text { Sildenafil } 2013 \\
\text { [59] }\end{array}$ & RELAX & 216 & $\begin{array}{l}\text { Heart failure, WHO FC } \\
\text { II-IV }\end{array}$ & $\begin{array}{l}\text { 1:1 randomisation } \\
24 \text {-week duration } \\
20 \mathrm{mg} \text { three times daily for } \\
12 \text { weeks, then } 60 \mathrm{mg} \text { three times } \\
\text { daily for } 12 \text { weeks }\end{array}$ & $\begin{array}{l}\text { Haemodynamics (change in } \\
\text { peak } V^{\prime} \mathrm{O}_{2} \text { ) }\end{array}$ & No effect \\
\hline $\begin{array}{l}\text { Riociguat } 2013 \\
\text { [48] }\end{array}$ & LEPHT & 201 & $\begin{array}{l}\text { Heart failure, WHO FC } \\
\text { II-IV }\end{array}$ & $\begin{array}{l}\text { 2:1:1:2 randomisation } \\
\text { 16-week duration } \\
0.5 \mathrm{mg}, 1 \mathrm{mg} \text { or } 2 \mathrm{mg} \text { three times } \\
\text { daily }\end{array}$ & Change in mPAP & No effect \\
\hline $\begin{array}{l}\text { Riociguat } 2014 \\
\quad[61]\end{array}$ & DILATE-1 & 39 & HFpEF & $\begin{array}{l}\text { 1:1:1:1 randomisation } \\
0.5 \mathrm{mg}, 1 \mathrm{mg} \text { or } 2 \mathrm{mg} \text { single dose }\end{array}$ & $\begin{array}{l}\text { Largest mPAP change from } \\
\text { baseline } \leqslant 6 \mathrm{~h} \text { after drug } \\
\text { administration }\end{array}$ & No effect \\
\hline $\begin{array}{l}\text { Tadalafil } 2015 \\
\text { [58] }\end{array}$ & $\mathrm{PITCH}-\mathrm{HF}$ & 23 & $\begin{array}{l}\text { Heart failure, } \\
\text { NYHA FC II-IV }\end{array}$ & $\begin{array}{l}2: 1 \text { randomisation } \\
\leqslant 3 \text {-year duration } \\
40 \mathrm{mg} \text { daily }\end{array}$ & $\begin{array}{l}\text { Cardiovascular mortality or } \\
\text { hospitalisation due to heart } \\
\text { failure }\end{array}$ & Trial terminated early \\
\hline $\begin{array}{l}\text { Macitentan } 2015 \\
\text { [57] }\end{array}$ & MELODY-1 & $\begin{array}{l}\text { Estimated } \\
\quad \text { enrolment }=60\end{array}$ & $\begin{array}{l}\text { CpcPH due to left } \\
\text { ventricular } \\
\text { dysfunction }\end{array}$ & $\begin{array}{l}1: 1 \text { randomisation } \\
12 \text {-week duration } \\
10 \mathrm{mg} \text { once daily }\end{array}$ & Safety and tolerability & Estimated completion quarter 42015 \\
\hline
\end{tabular}

WHO FC: World Health Organization functional class; PAWP: pulmonary artery wedge pressure; LVESV: left ventricular end-systolic volume; MRI: magnetic resonance imaging; PAP: pulmonary arterial pressure; SVR: systolic vascular resistance; PVR: pulmonary vascular resistance; $V^{\prime} \mathrm{O}_{2}$ : oxygen uptake; mPAP: mean pulmonary arterial pressure; HFpEF: heart failure with preserved ejection fraction; NYHA FC: New York Heart Association functional class; CpcPH: post-capillary pulmonary hypertension with a pre-capillary component. \#: identifier numbers listed are for the https://clinicaltrials.gov/ registry. 


\section{Case study part 2: follow-up}

Based on the patient's initial assessment, would you have diagnosed him with PH-LHD?

A volume challenge with $500 \mathrm{~mL}$ of normal saline during RHC did not result in an increase in PAWP. Despite his extensive cardiac risk factors and history, it was felt that the $\mathrm{PH}$ in this patient was predominantly group $1 \mathrm{PAH}$. Because of the severity, intravenous epoprostenol was initiated with slow titration, to reach a final initial dose of $6 \mathrm{ng} \cdot \mathrm{kg}^{-1} \cdot \mathrm{min}^{-1}$.

Surveillance RHC 1 year later (at an epoprostenol dose of $37 \mathrm{ng} \cdot \mathrm{kg}^{-1} \cdot \mathrm{min}^{-1}$ ) showed a right atrial pressure of $1 \mathrm{mmHg}$, right ventricular pressure of $71 / 7 \mathrm{mmHg}$, systolic/diastolic/mean PAP of 75/36/48 $\mathrm{mmHg}$, PAWP of $12 \mathrm{mmHg}$, cardiac output/cardiac index of 3.6/2.0 L $\cdot \mathrm{min}^{-1}$, PVR of $799 \mathrm{dyn} \cdot \mathrm{s} \cdot \mathrm{cm}^{-5}(9.9 \mathrm{Wood}$ units) and systemic vascular resistance of $2069 \mathrm{dyn} \cdot \mathrm{s} \cdot \mathrm{cm}^{-5}$ (25.9 Wood units). PVR was decreased by $36 \%$, the PVR/systemic vascular resistance ratio had increased from 0.35 to 0.39 , cardiac output had increased by $67 \%$ and the patient was WHO functional class II.

Interestingly, 4 years after his diagnosis, the patient's 33-year-old daughter was diagnosed with PAH. Genetic testing in the patient demonstrated a bone morphogenetic protein receptor 2 (BMPR2) mutation. This same mutation was present in the daughter.

Although many of the patient's clinical signs and risk factors were suggestive of PH-LHD, the presence of the BMPR2 mutation also demonstrated the likelihood of heritable PAH. This case, although somewhat atypical, demonstrates that in real life there can be more than one potential cause of $\mathrm{PH}$ and that such a scenario of multiple potential aetiologies of $\mathrm{PH}$ is not uncommon. In addition, it is important to remember that there is no standard presentation of PH-LHD, and that even cases that appear superficially to be PH-LHD may not be such. Thus, it is important to consider all aspects of the patient's condition. Diagnosing PH-LHD is certainly challenging, with considerable potential for misdiagnosis.

\section{Conclusion}

There are multiple unmet needs for patients with PH-LHD. Despite PH being a frequent complication of left heart disease, data on the true incidence are sparse. The differing methodology of epidemiological studies make estimation of incidence challenging, and this is compounded by variations in haemodynamic definitions and terminology, wide variations in disease presentations, and a lack of knowledge surrounding the aetiology and differing phenotypes of PH-LHD. The case presented here highlights the complexity of differentiating PH-LHD from other types of $\mathrm{PH}$, and the multiple factors that should be considered before confirming the diagnosis. Although there is no single pharmacotherapy that is specific for PH-LHD, there are promising signs that clinical trial designs will be adapted in the future to include patients with the most appropriate risk-benefit profile, and to select more relevant clinical end-points.

\section{Acknowledgements}

The authors would like to thank Kate Bradford from PAREXEL (Uxbridge, UK) for medical writing assistance, funded by Actelion Pharmaceuticals Ltd (Allschwil, Switzerland).

\section{References}

Oudiz RJ. Pulmonary hypertension associated with left-sided heart disease. Clin Chest Med 2007; 28: 233-241. Schmeisser A, Schroetter H, Braun-Dulleaus RC. Management of pulmonary hypertension in left heart disease. Ther Adv Cardiovasc Dis 2013; 7: 131-151.

3 Guazzi M, Borlaug BA. Pulmonary hypertension due to left heart disease. Circulation 2012; 126: 975-990.

4 Vachiery JL, Adir Y, Barbera JA, et al. Pulmonary hypertension due to left heart diseases. J Am Coll Cardiol 2013; 62: Suppl., D100-D108.

5 Fang JC, DeMarco T, Givertz MM, et al. World Health Organization Pulmonary Hypertension group 2: pulmonary hypertension due to left heart disease in the adult - a summary statement from the Pulmonary Hypertension Council of the International Society for Heart and Lung Transplantation. J Heart Lung Transplant 2012; 31: 913-933.

6 Barnett CF, De Marco T. Pulmonary hypertension associated with left-sided heart disease. Heart Fail Clin 2012; 8: 447-459.

$7 \quad$ Mathier MA. Pulmonary hypertension owing to left heart disease. Clin Chest Med 2013; 34: 683-694.

8 Adir Y, Amir O. Pulmonary hypertension associated with left heart disease. Semin Respir Crit Care Med 2013; 34: $665-680$.

9 Georgiopoulou VV, Kalogeropoulos AP, Borlaug BA, et al. Left ventricular dysfunction with pulmonary hypertension: Part 1: epidemiology, pathophysiology, and definitions. Circ Heart Fail 2013; 6: 344-354.

10 Guazzi M, Galiè N. Pulmonary hypertension in left heart disease. Eur Respir Rev 2012; 21: 338-346.

11 Haddad F, Kudelko K, Mercier O, et al. Pulmonary hypertension associated with left heart disease: characteristics, emerging concepts, and treatment strategies. Prog Cardiovasc Dis 2011; 54: 154-167.

12 Corte TJ, McDonagh TA, Wort SJ. Pulmonary hypertension in left heart disease: a review. Int J Cardiol 2012; 156 253-258.

13 Guazzi M, Arena R. Pulmonary hypertension with left-sided heart disease. Nat Rev Cardiol 2010; 7: 648-659.

14 Gehlbach BK, Geppert E. The pulmonary manifestations of left heart failure. Chest 2004; 125: 669-682. 
15 Moraes DL, Colucci WS, Givertz MM. Secondary pulmonary hypertension in chronic heart failure: the role of the endothelium in pathophysiology and management. Circulation 2000; 102: 1718-1723.

16 Casserly B, Klinger JR. Brain natriuretic peptide in pulmonary arterial hypertension: biomarker and potential therapeutic agent. Drug Des Devel Ther 2009; 3: 269-287.

17 Haddad F, Doyle R, Murphy DJ, et al. Right ventricular function in cardiovascular disease, part II: pathophysiology, clinical importance, and management of right ventricular failure. Circulation 2008; 117: $1717-1731$.

18 Lam CS, Roger VL, Rodeheffer RJ, et al. Pulmonary hypertension in heart failure with preserved ejection fraction: a community-based study. J Am Coll Cardiol 2009; 53: 1119-1126.

19 Bursi F, McNallan SM, Redfield MM, et al. Pulmonary pressures and death in heart failure: a community study. $J$ Am Coll Cardiol 2012; 59: 222-231.

20 Damy T, Goode KM, Kallvikbacka-Bennett A, et al. Determinants and prognostic value of pulmonary arterial pressure in patients with chronic heart failure. Eur Heart J 2010; 31: 2280-2290.

21 Leung CC, Moondra V, Catherwood E, et al. Prevalence and risk factors of pulmonary hypertension in patients with elevated pulmonary venous pressure and preserved ejection fraction. Am J Cardiol 2010; 106: 284-286.

22 Robbins IM, Newman JH, Johnson RF, et al. Association of the metabolic syndrome with pulmonary venous hypertension. Chest 2009; 136: 31-36.

23 Cheli M, Vachiery JL. Controversies in pulmonary hypertension due to left heart disease. F1000Prime Rep 2015; 7: 07.

24 Kiefer TL, Bashore TM. Pulmonary hypertension related to left-sided cardiac pathology. Pulm Med 2011; 2011 : 381787

25 Costard-Jackle A, Fowler MB. Influence of preoperative pulmonary artery pressure on mortality after heart transplantation: testing of potential reversibility of pulmonary hypertension with nitroprusside is useful in defining a high risk group. J Am Coll Cardiol 1992; 19: 48-54.

26 Simonneau G, Gatzoulis MA, Adatia I, et al. Updated clinical classification of pulmonary hypertension. J Am Coll Cardiol 2013; 62: Suppl., D34-D41.

27 Galiè N, Humbert M, Vachiery JL, et al. 2015 ESC/ERS Guidelines for the diagnosis and treatment of pulmonary hypertension. Eur Respir J 2015; 46: 903-975.

28 Watson CJ, Gupta SK, O'Connell E, et al. MicroRNA signatures differentiate preserved from reduced ejection fraction heart failure. Eur J Heart Fail 2015; 17: 405-415.

29 Guazzi M. Pulmonary hypertension in heart failure preserved ejection fraction: prevalence, pathophysiology, and clinical perspectives. Circ Heart Fail 2014; 7: 367-377.

30 Gerges C, Gerges M, Lang MB, et al. Diastolic pulmonary vascular pressure gradient: a predictor of prognosis in "out-of-proportion" pulmonary hypertension. Chest 2013; 143: 758-766.

31 Tedford RJ, Beaty CA, Mathai SC, et al. Prognostic value of the pre-transplant diastolic pulmonary artery pressure-to-pulmonary capillary wedge pressure gradient in cardiac transplant recipients with pulmonary hypertension. J Heart Lung Transplant 2014; 33: 289-297.

32 Wang X, Liu Y, Yuan Y, et al. Short-term prognostic factors in the patients after acute heart failure. Int J Clin Exp Med 2015; 8: 1515-1520.

33 Hoeper MM, Barbera JA, Channick RN, et al. Diagnosis, assessment, and treatment of non-pulmonary arterial hypertension pulmonary hypertension. J Am Coll Cardiol 2009; 54: Suppl., S85-S96.

34 Rosenkranz S, Preston IR. Right heart catheterization: best practice and pitfalls in pulmonary hypertension. Eur Respir Rev 2015; 24: 642-652.

35 Robbins IM, Hemnes AR, Pugh ME, et al. High prevalence of occult pulmonary venous hypertension revealed by fluid challenge in pulmonary hypertension. Circ Heart Fail 2014; 7: 116-122.

36 Hoeper MM, Bogaard HJ, Condliffe R, et al. Definitions and diagnosis of pulmonary hypertension. J Am Coll Cardiol 2013; 62: Suppl., D42-D50.

37 Shah RV, Semigran MJ. Pulmonary hypertension secondary to left ventricular systolic dysfunction: contemporary diagnosis and management. Curr Heart Fail Rep 2008; 5: 226-232.

38 Aronson D, Eitan A, Dragu R, et al. Relationship between reactive pulmonary hypertension and mortality in patients with acute decompensated heart failure. Circ Heart Fail 2011; 4: 644-650.

39 Ghio S, Gavazzi A, Campana C, et al. Independent and additive prognostic value of right ventricular systolic function and pulmonary artery pressure in patients with chronic heart failure. J Am Coll Cardiol 2001; 37: 183-188.

40 Tampakakis E, Leary PJ, Selby VN, et al. The diastolic pulmonary gradient does not predict survival in patients with pulmonary hypertension due to left heart disease. JACC Heart Fail 2015; 3: 9-16.

41 Dzudie A, Kengne AP, Thienemann F, et al. Predictors of hospitalisations for heart failure and mortality in patients with pulmonary hypertension associated with left heart disease: a systematic review. BMJ Open 2014; 4: e004843.

42 Miller WL, Grill DE, Borlaug BA. Clinical features, hemodynamics, and outcomes of pulmonary hypertension due to chronic heart failure with reduced ejection fraction: pulmonary hypertension and heart failure. JACC Heart Fail 2013; 1: 290-299.

43 de Groote P, Millaire A, Foucher-Hossein C, et al. Right ventricular ejection fraction is an independent predictor of survival in patients with moderate heart failure. J Am Coll Cardiol 1998; 32: 948-954.

44 Di Salvo TG, Mathier M, Semigran MJ, et al. Preserved right ventricular ejection fraction predicts exercise capacity and survival in advanced heart failure. J Am Coll Cardiol 1995; 25: 1143-1153.

45 Polak JF, Holman BL, Wynne J, et al. Right ventricular ejection fraction: an indicator of increased mortality in patients with congestive heart failure associated with coronary artery disease. J Am Coll Cardiol 1983; 2: 217-224.

46 Baker BJ, Wilen MM, Boyd CM, et al. Relation of right ventricular ejection fraction to exercise capacity in chronic left ventricular failure. Am J Cardiol 1984; 54: 596-599.

47 McLaughlin VV, Archer SL, Badesch DB, et al. ACCF/AHA 2009 expert consensus document on pulmonary hypertension: a report of the American College of Cardiology Foundation Task Force on Expert Consensus Documents and the American Heart Association developed in collaboration with the American College of Chest Physicians; American Thoracic Society, Inc.; and the Pulmonary Hypertension Association. J Am Coll Cardiol 2009; 53: 1573-1619. 

ventricular dysfunction: a phase IIb double-blind, randomized, placebo-controlled, dose-ranging hemodynamic study. Circulation 2013; 128: 502-511.

49 Packer M, McMurray J, Massie BM, et al. Clinical effects of endothelin receptor antagonism with bosentan in patients with severe chronic heart failure: results of a pilot study. J Card Fail 2005; 11: 12-20.

50 Kalra PR, Moon JC, Coats AJ. Do results of the ENABLE (Endothelin Antagonist Bosentan for Lowering Cardiac Events in Heart Failure) study spell the end for non-selective endothelin antagonism in heart failure? Int J Cardiol 2002; 85: 195-197.

51 Califf RM, Adams KF, McKenna WJ, et al. A randomized controlled trial of epoprostenol therapy for severe congestive heart failure: The Flolan International Randomized Survival Trial (FIRST). Am Heart J 1997; 134: 44-54.

52 Anand I, McMurray J, Cohn JN, et al. Long-term effects of darusentan on left-ventricular remodelling and clinical outcomes in the EndothelinA Receptor Antagonist Trial in Heart Failure (EARTH): randomised, double-blind, placebo-controlled trial. Lancet 2004; 364: 347-354.

53 Lewis GD, Lachmann J, Camuso J, et al. Sildenafil improves exercise hemodynamics and oxygen uptake in patients with systolic heart failure. Circulation 2007; 115: 59-66.

54 Guazzi M, Samaja M, Arena R, et al. Long-term use of sildenafil in the therapeutic management of heart failure. J Am Coll Cardiol 2007; 50: 2136-2144.

55 Lewis GD, Shah R, Shahzad K, et al. Sildenafil improves exercise capacity and quality of life in patients with systolic heart failure and secondary pulmonary hypertension. Circulation 2007; 116: 1555-1562.

56 Lüscher TF, Enseleit F, Pacher R, et al. Hemodynamic and neurohumoral effects of selective endothelin A (ET(A)) receptor blockade in chronic heart failure: the Heart Failure ET(A) Receptor Blockade Trial (HEAT). Circulation 2002; 106: 2666-2672.

57 ClinicalTrials.gov. Safety and tolerability of macitentan in subjects with combined pre- and post-capillary pulmonary hypertension due to left ventricular dysfunction (MELODY-1). https://clinicaltrials.gov/ct2/show/ NCT02070991 Date last accessed: July 21, 2015. Date last updated: September, 2015.

58 ClinicalTrials.gov. Phosphodiesterase type 5 inhibition with tadalafil changes outcomes in heart failure (PITCH-HF). https://clinicaltrials.gov/ct2/show/NCT01910389 Date last accessed: June 19, 2015. Date last updated: April, 2015.

59 Redfield MM, Chen HH, Borlaug BA, et al. Effect of phosphodiesterase-5 inhibition on exercise capacity and clinical status in heart failure with preserved ejection fraction: a randomized clinical trial. JAMA 2013; 309: $1268-1277$.

60 Finch KT, Stratton EA, Farber HW. Ranolazine as treatment of pulmonary hypertension associated with heart failure with preserved ejection fraction. Circulation 2013; 128: A10662.

61 Bonderman D, Pretsch I, Steringer-Mascherbauer R, et al. Acute hemodynamic effects of riociguat in patients with pulmonary hypertension associated with diastolic heart failure (DILATE-1): a randomized, double-blind, placebo-controlled, single-dose study. Chest 2014; 146: 1274-1285.

62 Hoendermis ES, Liu LC, Hummel YM, et al. Effects of sildenafil on invasive haemodynamics and exercise capacity in heart failure patients with preserved ejection fraction and pulmonary hypertension: a randomized controlled trial. Eur Heart J 2015; 36: 2565-2573.

63 Friedman SE, Andrus BW. Obesity and pulmonary hypertension: a review of pathophysiologic mechanisms. J Obes 2012; 2012: 505274.

64 Pugh ME, Newman JH, Williams DB, et al. Hemodynamic improvement of pulmonary arterial hypertension after bariatric surgery: potential role for metabolic regulation. Diabetes Care 2013; 36: e32-e33. 